\title{
HUBUNGAN FAKTOR TRAUMA MASA LALU DENGAN STATUS MENTAL BERISIKO GANGGUAN PSIKOSIS PADA REMAJA AKHIR DI DKI JAKARTA
}

\author{
CHARISMA DIAN USWATUN HASANAH \& TRI KURNIATI AMBARINI* \\ Departemen Psikologi Klinis dan Kesehatan Mental, Fakultas Psikologi Universitas Airlangga
}

\begin{abstract}
ABSTRAK
Tujuan dari penelitian ini adalah untuk mengkaji hubungan antara faktor yang menyebabkan trauma masa lalu dengan status mental berisiko gangguan psikosis pada remaja. Penelitian ini merupakan penelitian kuantitatif eksplanatori dengan analisis uji korelasi Spearman's rho dengan 183 subjek, terdiri dari 91 laki-laki dan 92 perempuan dengan kriteria remaja akhir berusia 17-24 tahun yang berdomisili di Jakarta. Penelitian ini menggunakan metode survey menggunakan kuisioner. Alat ukur yang digunakan untuk mengukur faktor trauma pada masa lalu adalah kuisioner faktor trauma pada masa lalu, sedangka alat ukur yang mengukur status mental berisiko gangguan psikosis adalah skala identifikasi status mental berisiko gangguan psikosis. Penelitian ini menghasilkan terdapat hubungan signifikan antara faktor trauma masa lalu dengan status mental berisiko gangguan psikosis. Hubungan ini memiliki kekuatan arah positif, artinya apabila seseorang memiliki nilai faktor trauma pada masa lalu yang tinggi maka risiko memiliki status mental berisiko juga akan tinggi.
\end{abstract}

Kata kunci: remaja, status mental berisiko gangguan psikosis, trauma masa lalu

\section{ABSTRACT}

This study aims to determine the correlation between factors of childhood trauma and at-risk mental state of psychosis among late adolescent. This is an explanatory research with Spearman's rho correlation test analysis, conducted on 183 subjects, which consisted of 91 males and 92 females, ranging from 17-24 years old domiciled in Jakarta. This study used a survey method with a questionnaire and used two scales to measure the variables, each of them was used to measures the factors of childhood trauma and at-risk mental state of psychosis disorder. Result of this study shows a significant correlation between factors of childhood trauma and at-risk mental state of psychosis. This correlation has a positive one-way correlation; a condition when someone with a high rate in factors of childhood trauma will have a tendency to have a high rate in at-risk mental state as well.

Keywords: adolescence, at-risk mental state of psychosis, childhood adversity

INSAN Jurnal Psikologi dan Kesehatan Mental, 2018, Vol. 3(2), pp, doi: 10.20473/jpkm.v3i22018.73-82

Dikirimkan: 16 Oktober 2019 Diterima: 10 Desember 2019 Diterbitkan: 26 Februari 2020

Editor: Atika Dian Ariana

*Alamat korespondensi: Fakultas Psikologi Universitas Airlangga, Jalan Airlangga 4-6 Surabaya 60286. Pos-el: tri.ambarini@psikologi.unair.ac.id

Naskah ini merupakan naskah dengan akses terbuka dibawah ketentuan the Creative Common Attribution License (http://creativecommons.org/licenses/by/4.0), sehingga penggunaan, distribusi, reproduksi dalam media apapun atas artikel ini tidak dibatasi, selama sumber aslinya disitir dengan baik. 


\section{P E N D A H U L U A N}

Masa remaja merupakan salah satu periode transisi dalam kehidupan manusia dari masa kanak-kanak menuju ke masa dewasa (Santrock, 2012). Masa ini merupakan masa yang rawan dalam rentang hidup manusia karena pada masa inilah manusia mengalami banyak perubahan-perubahan dan perkembangan, seperti perubahan fisik, psikis, emosional, dan biologis. Sesuai dari perubahan dan perkembangan yang dialami, maka remaja memiliki tugas perkembangan yang harus diselesaikan, seperti mampu menerima keadaan fisiknya, mampu berhubungan baik dengan teman sebayanya baik itu sesama jenis maupun lawan jenis, dapat memahami peran seksualnya, mencapai kemandirian emosional dan mampu mengembangkan konsep dan keterampilan intelektual (Manurung, 2011, dalam Astuti, 2012). Jika dalam melaksanakan tugas perkembangan ini remaja mengalami gangguan, maka tumbuh kembang remaja akan terganggu pula.

Dalam menjalani tugas perkembangannya, remaja juga akan mengalami beberapa konflik hingga berdampak pada munculnya perasaan tidak aman, cemas, dan depresi (Hall, 1904, dalam Rahmah, 2018). Menurut Arnett (2006), konflik yang terjadi pada remaja adalah konflik dengan orang tua dan kecenderungan untuk melakukan perilaku berisiko yang dapat menyebabkan munculnya gangguan kesehatan, baik fisik maupun mental di masa depannya. Faktor-faktor seperti lingkungan sekolah yang negatif, pengalaman negatif yang menyebabkan buruknya hubungan dengan keluarga maupun teman sebaya dianggap menjadi pemicu munculnya konflik pada remaja.

Pengalaman traumatis yang dialami pada masa kanak-kanak juga dapat memicu persoalan yang muncul pada masa remaja. Data dari Riskedas tahun 2013 menunjukkan bahwa prevalensi gangguan mental yang ditunjukkan dengan gejala depresi dan kecemasan pada individu berusia 15 tahun keatas mencapai 14 juta orang atau 6\% dari jumlah penduduk Indonesia. Menurut McGuigan dan Pratt (2011 dalam Margaretha, Nuringtyas, \& Rachim, 2013) pengalaman traumatis yang dialami seseorang pada masa kanak merupakan prediktor munculnya permasalahan mental yang serius di masa dewasanya.

Trauma pada masa kanak-kanak merupakan pengalaman yang menyakitkan bagi seseorang yang dapat menyebabkan dampak terhadap fisik maupun mental. American health maintenance organization Kaiser Permanente and the Centers for Disease Control and Prevention mengembangkan penelitian tentang hal ini dengan istilah Adverse Childhood Experience (ACE) pada tahun 1997 yang dipimpin oleh Feliti dan Anda. Penelitian ini berawal karena tingginya angka anak-anak yang mengidap permasalahan kesehatan yang berat hingga dapat menyebabkan kematian dini. Hasil pada penelitian ini menunjukkan anak yang memiliki trauma dan mengalami berat badan yang berlebihan, hal itu karena makan dapat menjadi salah satu mekanisme koping yang dilakukan anak untuk depresi, kecemasan, dan ketakutannya (Cristóbal-Narváez dkk., 2016). Istilah childhood adversity ini telah digunakan dalam beberapa literatur untuk mencakup berbagai pengalaman, seperti berbagai macam bentuk kekerasan fisik, seksual dan pengabaian secara fisik dan emosional, dan memiliki keluarga yang disfungsi, seperti kehilangan orang terdekat, menyaksikan KDRT, hidup dengan anggota keluarga yang menyalah gunakan zat dan alkohol, dan anggota keluarga yang mengidap gangguan jiwa (World Health Organization, 2018)

Menurut WHO (2012), pengalaman negatif dirumah maupun di lingkungan sekolah yang dialami oleh anak dapat mengakibatkan dampak buruk bagi perkembangan kognitif dan emosionalnya. Orang tua yang suportif, kondisi keluarga yang aman dan nyaman, dan lingkungan belajar anak yang positif adalah kunci dari faktor pelindung anak dari kesehatan mental yang akan dikembangkan oleh anak. Risiko memiliki gangguan kesehatan mental akan lebih tinggi bagi anak yang sering mengalami keluarga yang sering konflik, kekerasan yang dialami keluarga maupun kekerasan oleh anggota keluarga, pengalaman-pengalaman negatif. Dampak yang lebih parah dari pengalaman-pengalaman yang lebih ekstrim seperti kehilangan orang tua atau orang tua (pada umumnya ibu) yang menjadi INSAN Jurnal Psikologi dan Kesehatan Mental Tahun 2018, Vol. 3(2), 73-82 doi: 10.20473/jpkm.v3i22018.73-82 
korban kekerasan, akan mengakibatkan risiko trauma yang lebih besar dan memiliki efek yang berkepanjangan selama hidupnya.

Psikosis, dalam DSM 5, diidentifikasikan sebagai gangguan yang muncul sepanjang spektrum skizoid dan skizofrenia yang menentukan ringan atau beratnya gangguan yang diderita. Selain itu, psikosis menjadi salah satu dari beberapa dimensi gangguan neuropsikiatri, dengan mencangkup perilaku psikomotor yang abnormal, gangguan kognitif, dan emosional. Halusinasi dan delusi merupakan dampak yang timbul dari sistem saraf yang menerima dan mengolah informasi, sehingga pengidap gangguan ini mengalami putus kontak terhadap realitas (Arciniegas, 2015).

Menurut WHO (2018) gangguan kesehatan mental yang paling kronis merupakan gangguan skizofrenia, yang merupakan salah satu bagian dari gangguan psikosis, dengan prevalensi mencapai 21 juta orang dari populasi dunia. Berdasarkan penelitian yang dilakukan oleh McGrath, Saha, Chant, dan Welham (2008) menunjukkan bahwa sekitar 100.000 remaja dan individu dewasa awal di Amerika Serikat setidaknya mengalami episode awal psikosis di tiap tahunnya. Sedangkan di Indonesia sendiri, menurut data dari Riset Kesehatan Dasar (Riskedas) tahun 2013 menyatakan bahwa prevalensi gangguan jiwa berat seperti psikosis dan skizofrenia mencapai sekitar 400.000 orang atau sebanyak 1,7 per 1.000 penduduk Indonesia, dengan prevalensi terbanyak ditemukan di daerah Aceh dan DI Yogyakarta dengan angka 0.27 per 1.000 penduduk.

Menurut Riskedas (2007) prevalensi gangguan jiwa berat tertinggi terdapat di provinsi DKI Jakarta sebanyak 20,3\% sedangkan prevalensi nasional adalah 4.6\%. Pada tahun 2013, prevalensi gangguan jiwa di DKI Jakarta menurun menjadi 1.1\%, sedangkan prevalensi nasional menunjukkan angka 1.7\%. Penelitian terbaru yang dilakukan oleh Riskedas tahun 2018 tentang keluarga dengan anggota yang mengidap gangguan psikosis atau skizofrenia sejak tahun 2013 hingga 2018 menghasilkan data bahwa prevalensi nasional terjadi peningkatan yang cukup signifikan menjadi 7\% dan prevalensi DKI Jakarta terjadi peningkatan yang sangat signifikan dari 1.1\% hingga menduduki prevalensi yang sama dengan prevalensi nasional yaitu 7\% (per mil) (Riskesdas, 2018).

Belum diketahui secara spesifik kelompok usia yang memiliki angka lebih tinggi untuk mengalami simtom awal dari gangguan psikosis, namun menurut McFarlane (2011) kemunculan paling dini yang dapat berkembang menjadi tandatanda psikosis muncul saat masa remaja akibat dari proses neurodegeneratif dan stres secara psikososial dan perubahan hormonal. Ditambah lagi, penelitian longitudinal selama 15 tahun yang dilakukan oleh Pulton, dkk. (2000, dalam Stevens, Prince, Prager, \& Stern, 2014) melaporkan bahwa $14 \%$ anak berusia 11 tahun menyumbang simtom psikosis berdasarkan wawancara yang dilakukan dan berkaitan dengan meningkatnya terpaparnya gangguan psikosis pada masa dewasa awal sebanyak 5-16 kali lipat (tergantung dari seberapa parahnya simtom yang dimunculkan). Setelah penelitian itu dilakukan, penelitian lain dengan skala populasi yang besar pun dilakukan, salah satunya adalah penelitian longitudinal lainnya dengan subjek siswa tingkat sekolah menengah atas berbasis kuisioner dan pencegahan bunuh diri menemukan hal bahwa 34\% siswa mengalami halusinasi dan diikuti percobaan untuk bunuh diri (Stevens, Prince, Prager, \& Stern, 2014).

Sebelum mengalami gangguan psikosis terdapat fase perkembangan gangguan psikosis, yang disebut status mental berisiko gangguan psikosis. Fase ini merupakan fase dimana seseorang belum sepenuhnya didiagnosis mengidap gangguan psikosis, atau biasanya individu tersebut berada pada episode awal yang dengan secara bertahap, fase tersebut disebut dengan istilah prodromal. Istilah prodromal pertamakali dikenalkan oleh Mayer-Gross pada tahun 1932 dalam jurnalnya "Die Klinik der Schizophrenie" (Rahmah, 2018). Prodromal pada gangguan psikosis dapat diartikan sebagai periode awal yang dapat ditandai dengan munculnya perubahan pada perasaan, pikiran, persepsi, dan perilaku yang dapat mengarah kepada gangguan psikosis itu sendiri, sedangkan gejala-gejala yang sudah dapat INSAN Jurnal Psikologi dan Kesehatan Mental Tahun 2018, Vol. 3(2), 73-82 doi: 10.20473/jpkm.v3i22018.73-82 
diobservasi secara jelas yang ada pada psikosis, seperti waham atau delusi dan halusinasi, belum terlihat secara jelas sehingga individu tersebut tidak bisa ditetapkan secara $100 \%$ akan mengidap gangguan psikosis (Yung \& Stanley, 1998). Yung, dkk., (1996) mengumpamakan fase prodromal ini dengan penyakit campak. Gejala-gejala yang ditimbulkan oleh penyakit campak tidak terlalu spesifik sehingga sulit untuk dipastikan bahwa individu tersebut benarbenar terkena campak. Sama halnya dengan fase prodormal, diagnosa tidak bisa ditegakkan karena gejala yang muncul tidak spesifik.

Menurut McGorry dan Singh (1995), status mental berisiko gangguan psikosis adalah istilah untuk menggambarkan gejala awal psikosis pada seseorang, namun belum tentu akan berkembang menjadi gangguan yang lebih serius. Sedangkan menurut Fusar-Poli, Radua, McGuire, dan Borgwardt (2011) mengatakan bahwa status mental berisiko gangguan psikosis merupakan fase seseorang yang memunculkan gejala-gejala psikosis yang cukup kuat sehingga diprediksikan dalam 4 tahun kedepan individu tersebut kemungkinan besar dapat didiagnosa mengidap gangguan psikosis.

Dalam beberapa penelitian yang disebutkan oleh Cristóbal-Narváez, dkk., (2016), telah terbukti bahwa kesulitan pada masa kanak-kanak dapat menimbulkan risiko yang lebih tinggi untuk memunculkan simtom dari beberapa domain gangguan psikosis. Dampak-dampak buruk yang ditimbulkan dari gangguan psikosis ini sangat beragam, mulai dari penurunan fungsi dalam aspek kognitif, afektif, sosial, dan permasalahan di tempat kerja atau sekolah (Cornblatt dkk., 2012). Maka dari itu, intervensi dini pada orang-orang yang memiliki status mental berisiko dapat dilakukan untuk memperlambat hingga menghilangkan kemungkinan untuk mengembangkan gejala psikosis lebih lanjut agar menurunkan angka gangguan kejiwaan berat.

Lingkungan keluarga pada masa kanak-kanak dapat menjadi prediktor untuk memahami kesehatan fisik dan mental seseorang sepanjang hidupnya. Keadaan disfungsional dalam keluarga menyebabkan kerentanan pada diri anggota keluarganya. Dampak lain yang ditimbulkan dari keluarga yang disfungsional adalah jika individu yang semula adalah korban, kemudian belajar dari pola hidup yang disfungsional tersebut yang duperoleh dari keluarganya, di masa depannya individu tersebut memiliki kemungkinan akan menjadi pelaku dan akhirnya membangun keluarga yang disfungsional pula (Margaretha, Nuringtyas, \& Rachim, 2013)

Keith dan Mathew (1991, dalam Yung \& McGorry, 1996) mendeskripsikan bahwa psikosis terjadi secara bertahap yang diawali dengan gejala-gejala kecil yang berhubungan dengan munculnya psikosis, yang lebih dikenal dengan istilah 'prodromal'. Prodromal sendiri diambil dari kata Yunani, prodromos, yang berarti awal mula dari suatu hal (Fava \& Kellner, 1991, dalam Yung \& McGorry, 1996). Menurut Yung dan McGorry (1996) dalam dunia medis sendiri, prodromal mengacu pada simtom dan tanda-tanda awal dari penyakit sebelum gejala itu berkembang menjadi penyakit secara sempurna.

Kejadian traumatis yang dialami pada masa kanak-kanak merupakan pengalaman yang umum dijumpai pada seseorang. Diperkirakan satu per tiga populasi umum di dunia yang memiliki trauma masa kanak-kanak mengalami dampak negatif di kehidupan sosial, seperti meningkatnya kecenderungan melakukan tindakan kriminal, rendahnya tingkat pendidikan, dan rendahnya kesehatan secara umum dan kesejahteraan. Pengalaman ini juga menjadi pengaruh terhadap munculnya risiko yang besar terpapar gangguan mental. Studi terkait tentang Adverse Childhood Experience menghasilkan data bahwa kekerasan pada anak (fisik dan psikologis, seksual dan bully), pengabaian dan disfungsi dalam keluarga menyebabkan risiko terpaparnya penyakit kronis dan gangguan yang mental di masa dewasanya (Varese dkk., 2012). Setiap anak memiliki kebutuhan perawatan dasar untuk bertahan hidup. Tanpa makanan yang cukup, tempat berlindung, dan proteksi, mereka tidak akan mungkin untuk dapat tumbuh dan berkembang sesuai dengan tahapan perkembangan hingga ia dewasa. Pengabaian yang ekstrim dapat mengarah kepada 'dibuang'nya bayi INSAN Jurnal Psikologi dan Kesehatan Mental Tahun 2018, Vol. 3(2), 73-82 doi: 10.20473/jpkm.v3i22018.73-82 
ke tempat yang tidak layak atau anak yang dibiarkan menderita akibat kelaparan dan kurangnya perhatian akan kesehatannya.

Menurut Feteliti, dkk. (1998, dalam Giardino, Lyn, \& Giardino, 2010), disfungsi dalam rumah tangga adalah permasalahan yang dialami dalam sebuah keluarga, dapat berupa tinggal dengan anggota keluarga yang memiliki permasalahan dengan penyalah gunaan zat (peminum alkohol berat, penggunaan narkoba), gangguan jiwa, pelaku kriminal, atau salah satu orang tua (pada umumnya ibu) yang diperlakukan dengan kasar (didorong, dipukul, ditampar, digigit, dipukul dengan benda tumpul atau dengan kepalan tangan, dilempar dengan sesuatu) dengan intensitas yang sering atau hampir berulang kali, atau pernah diancam dengan atau tanpa senjata, seperti pisau atau pistol.

Pada penelitian ini, hipotesis yang menjadi dasar sesuai dengan latar belakang dan kajian pustaka yang telah dijabarkan sebelumnya adalah sebagai berikut; H0: Tidak adanya hubungan yang signifikan antara pengabaian secara emosional dan disfungsi keluarga sebagai faktor dari trauma masa lalu dengan status mental berisiko gangguan psikosis pada remaja di Jakarta. Ha: Adanya hubungan signifikan pengabaian secara emosional dan disfungsi keluarga sebagai faktor dari trauma masa lalu dengan status mental berisiko gangguan psikosis pada remaja di Jakarta.

\section{MET OD E}

\section{Partisipan}

Populasi pada penelitian ini merupakan remaja akhir berusia 17 - 24 tahun, belum menikah, dan berdomisili di Jakarta.

\section{Prosedur}

Teknik pengumpulan data yang digunakan oleh peneliti adalah teknik survei cross-sectional dengan menggunakan kuisioner sebagai instrumen pengumpulan data

\section{Pengukuran}

Alat ukur dari variable Status Mental Berisiko Psikosis diukur menggunakan Skala Identifikasi Status Mental Berisiko yang dikembangkan oleh Ambarini (2019) berdasarkan teori yang dikembangkan oleh Yung, dkk. (2004). Alat ukur ini terdiri dari 40 item dengan pilihan yang menggunakan skala Likert.

Analisis data

Penelitian ini menggunakan analisis korelasi Spearman's Rho yang diolah menggunakan SPSS 22.

\section{HAS IL PENELIT IAN}

\section{Uji Reliabilitas Alat Ukur}

Alat ukur skala identifikasi status mental berisiko yang dikembangkan oleh Ambarini (2019) terdiri dari 40 aitem dengan 7 skala respon sangat reliabel $(\alpha=0,941)$. Untuk alat ukur faktor risiko status mental berisiko yang dikembangkan oleh Ambarini (2019) juga reliabel $(\alpha=0,791)$. 
Tabel 1. Hasil Uji Reliabilitas

\begin{tabular}{lcc}
\hline \multicolumn{1}{c}{ Alat Ukur } & N & Cronbach's Alpha \\
\hline $\begin{array}{l}\text { Skala Identifikasi Status } \\
\text { Mental Berisiko Psikosis } \\
\text { (Ambarini, 2019) }\end{array}$ & 40 & 0,941 \\
$\begin{array}{l}\text { Faktor Risiko Trauma Masa } \\
\text { Lalu (Ambarini, 2019) }\end{array}$ & 33 & 0,791 \\
\hline
\end{tabular}

\section{Analisis statistik deskriptif}

Setelah dilakukan uji analisis deskriptif, didapatkan hasil yang telah disajikan di tabel 2. Berdasarkan dari hasil analisis tersebut, variabel dari faktor- faktor yang menyebabkan status mental berisiko gangguan psikosis memiliki nilai maksimum 111, nilai minimum 27, dan nilai rata-rata sebesar 64.43. Hasil ini menunjukkan bahwa dari sebanyak 183 responden yang mengisi kuisioner Faktor Berisiko Gangguan Psikosis dengan 33 aitem, nilai terendah yang diperoleh adalah 27 dan yang nilai tertinggi adalah 111. Untuk pendistribusian data didapatkan nilai skewness sebesar 0.449 dan nilai kurtosis sebesar -0.531. Hal ini menunjukkan bahwa pendistribusian data tersebar secara simetris dengan kurva lonceng yang condong ke kanan dan bersifat homogen.

Tabel 2. Hasil Analisis Statistik Deskriptif

\begin{tabular}{lll}
\hline & $\begin{array}{c}\text { Faktor Risiko Trauma } \\
\text { Masa Lalu }\end{array}$ & $\begin{array}{c}\text { Skala Status Mental } \\
\text { Berisiko Gangguan } \\
\text { Psikosis }\end{array}$ \\
\hline $\mathrm{N}$ & 183 & 183 \\
Nilai Maksimum & 111 & 210 \\
Nilai Minimum & 27 & 1 \\
Nilai Rata-rata & 64.43 & 77,47 \\
Standar Deviasi & 18,372 & 37,482 \\
Skewness & 0,449 & 0,391 \\
Kurtosis & $-0,531$ & 0,029 \\
\hline
\end{tabular}

\section{Uji normalitas data}

Berdasarkan hasil analisis, untuk variabel Skala Identifikasi Status Mental Berisiko Psikosis memiliki distribusi data yang normal $(p=0.2)$. Namun untuk variabel pengabaian $(p=0.000)$ dan disfungsi keluarga $(p=0.009)$ dapat dikatakan pendistribusian data tidak normal. Alasan mengapa data tidak berdistribusi normal adalah terdapatnya outlier, yaitu data yang memiliki skor ekstrim, baik ekstrim tinggi ataupun ke kanan sehingga menyebabkan distribusi condong ke kiri atau ke kanan.

\section{Uji linearitas}

Berdasarkan analisis, jika ditinjau dari probabilitas linearity dapat diasumsikan bahwa data antar variabel pengabaian dan disfungsi keluarga dengan skala identifikasi status mental berisiko ada pada garis yang linear $(p=0.000)$. Jika dilihat dari probabilitas deviation from linearity, variabel disfungsi keluarga liniear $(p=0.077)$. Namun pada variabel pengabaian, hubungan antar variabel adalah tidak linear $(p=0.001)$. Dengan demikian, data pada penelitian ini dapat dikatakan linear karena probabilitas data pada nilai linearity sudah tepenuhi, yaitu data yang mengikuti garis linear cukup besar.

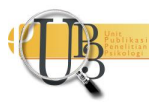




\section{Uji korelasi}

Dari hasil analisis diketahui bahwa kedua variabel memiliki korelasi yang cenderung lemah dan signifikan dengan skala identifikasi status mental berisiko psikosis $(p<0.05)$. Untuk nilai korelasi, kedua variabel memiliki korelasi yang positif. Artinya kekuatan hubungan korelasi adalah searah, yaitu ketika seseorang memiliki pengalaman diabaikan $(r(183)=0.244, p=0.001)$ atau memiliki keluarga yang disfungsi saat masa kanak-kanak $(r(183)=0.421, p=0.000)$, maka mereka memiliki kerentanan berada pada status mental berisiko mengalami gangguan psikosis. Maka dapat diasumsikan bahwa tingkat korelasi tiap variabel tergolong rendah. Meski tergolong rendah, pengabaian dan disfungsi keluarga memiliki hubungan yang signifikan terhadap status mental berisiko gangguan psikosis.

\section{I S K US I}

Status mental berisiko gangguan psikosis menjadi salah satu alat ukur untuk menunjukkan kondisi seseorang yang memiliki kerentanan gangguan psikosis sebelum gejala psikosis muncul. Belum diketahui secara spesifik untuk kelompok usia yang memiliki risiko lebih tinggi untuk mengalami periode ini, namun kemunculan yang paling dini adalah saat masa remaja. Hal ini diakibatkan karena proses neurodegeneratif dan stres secara psikososial dan perubahan secara hormonal. Di DKI Jakarta sendiri, 7\% dari populasi kota tersebut atau sekitar 700 ribu jiwa mengidap gangguan jiwa jenis skizofrenia, hal ini merupakan isu yang harus segera ditanggulangi.

Pada penelitian sebelumnya sudah diketahui beberapa faktor trauma pada masa lalu yang dapat memengaruhi kerentanan seseorang memiliki gangguan psikosis. Penelitian ini bertujuan untuk memperkaya data dari penelitian sebelumnya dengan menambahkan teori bahwa faktor-faktor yang menjadi penyebab trauma pada masa kanak-kanak tidak hanya berada pada kekerasan fisik, seksual, dan menjadi korban bully, namun faktor lain seperti pengabaian secara emosional dan disfungsi dalam keluarga yang dialami seseorang sebelum berusia 17 tahun juga dapat mengakibatkan trauma pada masa lalunya.

Pada penelitian ini, bertujuan untuk mengetahui adakah hubungan antara pengabaian secara emosional dan disfungsi dalam keluarga yang menjadi faktor dari trauma masa lalu dengan status mental berisiko gangguan psikosis. Hal ini menjadi hipotesis yang menjadi dasar dari penelitian ini. Sebelum melakukan uji analisis, data diharuskan untuk di uji asumsi terlebih dahulu, yaitu uji normalitas dan linearitas. Uji asumsi pada penelitian ini menghasilkan bahwa pendistribusian data bersifat tidak normal, namun linear. Berdasarkan dari hasil uji normalitas tersebut akhirnya menentukan teknik statistik yang digunakan pada penelitian ini adalah teknik statistik non-parametrik uji korelasi Spearman"s rho.

Dari hasil uji analisis ini, didapatkan koefisien korelasi antara status mental berisiko dan trauma masa lalu cenderung lemah dan positif. Hubungan positif yang dihasilkan pada penelitian ini menunjukkan bahwa semakin tinggi skor yang dimiliki pada faktor-faktor trauma pada masa lalu yang dialami seseorang, maka semakin tinggi pula kerentanan seseorang untuk berada pada status mental berisiko mengalami gangguan psikosis.

Hasil analisis ini didukung oleh teori dari WHO (2018) yang menyatakan bahwa pengabaian dan disfungsi dalam keluarga yang merupakan bagian dari faktor-faktor yang menyebabkan childhood adversity atau pengalaman traumatis yang didapatkan seseorang pada masa kanak-kanaknya dapat dikatakan sebagai faktor yang menyebabkan trauma pada masa lalu dapat menyebabkan rentannya seseorang mengidap status mental berisiko gangguan psikosis pada masa remaja nya. Anak-anak yang 
mengalami trauma pada masa lalunya akan mengalami kesulitan pada masa remaja nya karena kurangnya persiapan untuk menjalani proses perkembangan hingga dapat menyebabkan fungsi fungsi yang ada pada dirinya tidak berkembang secara optimal, seperti fungsi sosial, kognitif, maupun afektif (Cristóbal-Narváez, dkk., 2016).

Hasil analisis tambahan menghasilkan data bahwa responden dengan jenis kelamin laki-laki memiliki kecenderungan lebih tinggi untuk memiliki status mental berisiko psikosis. Hal ini dapat didukung oleh beberapa penelitian yang dilakukan sebelumnya yang menunjukkan bahwa laki-laki memiliki kecenderungan lebih tinggi untuk memunculkan gejala skizofrenia daripada perempuan. Penemuan ini dapat dijadikan sebagai intervensi dini sebelum seseorang memunculkan gejala skizofrenianya agar dapat ditangani dengan baik sehingga dapat mengurangi atau bahkan menghilangkan kemungkinan individu tersebut untuk melanjutkan simtom-simtom yang ada pada dirinya menjadi gangguan yang lebih parah.

\section{S I M P U L A N}

Berdasarkan hasil penelitian ini, dapat disimpulkan bahwa terdapat hubungan yang signifikan antara pengabaian emosional dan disfungsi keluarga sebagai faktor-faktor yang menyebabkan trauma pada masa lalu dengan status mental berisiko gangguan psikosis pada remaja akhir di Jakarta dengan arah hubungan yang positif, dengan demikian dapat diketahui pada hasil penelitian ini adalah ketika seseorang mengalami trauma pada masa lalunya, maka individu tersebut juga memiliki risiko yang lebih tinggi untuk mengalami status mental berisiko psikosis.

\section{UCAPA N TERIMAKASIH}

Penulis berterima kasih khususnya kepada Tuhan Yang Maha Esa atas segala berkah dan nikmat yang dilimpahkan-Nya, untuk Ibu Tri Kurniati Ambarini, M. Psi selaku dosen pembimbing, untuk Ayah, Ibu, dan teman-teman sebagai salah satu support system penulis dan kepada seluruh responden dalam penelitian ini sehingga penelitian dapat terselesaikan dengan baik. Terima kasih.

\section{DEKLARASI POTENSI TERJADINYA KONFLIK KEPENTINGAN}

Charisma Dian Uswatun Chasanah dan Tri Kurniati Ambarini tidak bekerja, menjadi konsultan, memiliki saham, atau menerima dana dari perusahaan atau organisasi mana pun yang akan mengambil untung dari naskah ini, dan telah mengungkapkan bahwa ia tidak memiliki afiliasi selain yang telah disebut di atas.

\section{PUSTAKA ACUAN}

Arciniegas, D. B. (2015). Psychosis. Behavioral Neurology and Neuropsychiatry, 715-736.

Arnett, J. J. (2006). G. Stanley Hall's adolescence: Brilliance and nonsense. History of Psychology, 9(3), 186-197. https://doi.org/10.1037/1093-4510.9.3.186

Astuti, H. P. (2012). Buku Ajar Asuhan Kebidanan Obu I (Kehamilan). Yogyakarta: Rohima Press.

Cornblatt, B. A., Carrión, R. E., Addington, J., Seidman, L., Walker, E. F., Cannon, T. D., ... Lencz, T. (2012). Risk factors for psychosis: Impaired social and role functioning. Schizophrenia Bulletin, 38(6), 1247-1257. https://doi.org/10.1093/schbul/sbr136

Cristóbal-Narváez, P., Sheinbaum, T., Ballespí, S., Mitjavila, M., Myin-Germeys, I., Kwapil, T. R., \& INSAN Jurnal Psikologi dan Kesehatan Mental Tahun 2018, Vol. 3(2), 73-82 
Barrantes-Vidal, N. (2016). Impact of Adverse Childhood Experiences on Psychotic-Like Symptoms and Stress Reactivity in Daily Life in Nonclinical Young Adults. PloS One, 11(4), e0153557. https://doi.org/10.1371/journal.pone.0153557

Fusar-Poli, P., Broome, M. R., Matthiasson, P., Woolley, J. B., Mechelli, A., Johns, L. C., ... McGuire, P. (2011). Prefrontal function at presentation directly related to clinical outcome in people at ultrahigh risk of psychosis. Schizophrenia Bulletin, 37(1), 189-198. https://doi.org/10.1093/schbul/sbp074

Giardino, A. P., Lyn, M. A., \& Giardino, E. R. (2010). A Practical Guide to the Evaluation of Childhood Physical Abuse and Neglect. New York: Springer.

Margaretha, M., Nuringtyas, R., \& Rachim, R. (2013). Childhood Trauma of Domestic Violence and Violence in Further Intimate Relationship. Makara Human Behavior Studies in Asia, 17(1), 33. https://doi.org/10.7454/mssh.v17i1.1800

McFarlane, W. R. (2011). Prevention of the First Episode of Psychosis. Psychiatric Clinics of North America, 34(1), 95-107. https://doi.org/10.1016/j.psc.2010.11.012

McGorry, P. D., \& Singh, B. S. (1995). No Title. New York: Elsevier Ltd.

McGrath, J., Saha, S., Chant, D., \& Welham, J. (2008). Schizophrenia: A concise overview of incidence, prevalence, and mortality. Epidemiologic Reviews, 30(1), 67-76. https://doi.org/10.1093/epirev/mxn001

Rahmah, M. (2018). Hubungan Trauma Masa Kanak Dengan Status Mental Berisiko Gangguan Psikosis Pada Remaja. Universitas Airlangga.

Riskesdas. (2018). Riset Kesehatan Dasar 2018. In Kementrian Kesehatan Republik Indonesia. https://doi.org/1 Desember 2013

Santrock, J. M. (2012). Life-Span Development. Jakarta: Erlangga.

Stevens, J. R., Prince, J. B., Prager, L. M., \& Stern, T. A. (2014). Psychotic Disorders in Children and Adolescents: A Primer on Contemporary Evaluation and Management. The Primary Care Companion for CNS Disorders, 16(2).

Varese, F., Smeets, F., Drukker, M., Lieverse, R., Lataster, T., Viechtbauer, W., ... Bentall, R. P. (2012). Childhood adversities increase the risk of psychosis: A meta-analysis of patient-control, prospective-and cross-sectional cohort studies. Schizophrenia Bulletin, 38(4), 661-671. https://doi.org/10.1093/schbul/sbs050

World Health Organization. (2012). Investing on Mental Health. Retrieved March 7, 2019, from https://www.who.int/mental_health/mhgap/risks_to_mental_health_EN_2 7_08_12.pdf

World Health Organization. (2018). Violence and Injury Prevention. Retrieved October 9, 2018, from https://www.who.int/violence_injury_prevention/violence/activities/adverse_childhood_experi ences/en/

Yung, A. P., \& Stanley, P. A. (1998). Problems in Clinical Medicine. Sydney: MacLennan and Petty.

Yung, A. R., \& McGorry, P. D. (1996). The Prodromal Phase of First-Episode Psychosis : Past and Current Conceptualizations. 22(2), 335-370. 